\section{Lonrho Revisited: Witch-hunt, Crusade, Quest for EI Dorado, Road to Darien?}

Review of Department of Trade, Lonrho Ltd.: Investigations under Section 165(b) of the Companies Act 1948: Report by Allan Heyman, QC and Sir William Slimmings, CBE, CA pp. $660+16$ appendices, HMSO, London, 1976, $£ 13.20$.

Lonrho, Statement, (by Cameron Kemm Nordon, solicitors to Lonrho), London, 1976, 19pp, mimeo. Lonrho, Memorandum, (by the Solicitors and Robert Wright, QC), London, 1976, 44pp, mimeo. Suzanne and Gillian Cronje and Margaret Ling, Lonrho: Portrait of a Multinational Julian Friedmann 1976, £6.95, Penguin $£ 1.50$.

\section{Reginald Herbold Green}

Three years after Lonrho made the front pages with its "battle of the boardroom" and $\mathrm{Mr}$. Heath characterised it as the "unacceptable face of capitalism there is a rather more muted flurry as studies begun at that time emerge from the press.

With about 1,250 pages of reading matter one might assume that a clear picture of Lonrho would emerge but it is not so. None of the volumes tells much about Lonrho's financial results for its shareholders, its economic impact on its hosts (in any quantifiable sense and contrasted to any alternatives), its rather special nature as an entrepreneur of financial opportunism crossed with a pack rat and its highly disaggregated approach to group management and control. Indeed two brief press reports: 'A loose style of ownership' (Financial Times, November 5,1976, p. 19) and 'flat-footed', Economist November 20,1976 , p. 134), are at least as illuminating about the last two areas as the three major tomes together!

Any number of issues can be pursued from the material now made available, but three appear especially significant :

The state of company law and inspection;

The state of Lonrho;

The "unacceptable face of capitalism" as exemplified-or otherwise-by Lonrho and as revealed - or otherwise--in the volumes.

The immediate reaction to the Inspectors' Report must be that it neither paints a coherent picture of Lonrho, gives the shareholders much basis for considered action, seriously explores the legal or moral transgressions (if any) of Lonrho or its key figures, nor presents what it does find in an accessible manner. Further, it is wildly uneven in harshly criticising possible poor judgement (and the Inspectors' views on this are none too convincing at times) while glossing over what the man in the street (or in the City or in No. 10 Downing Street in 1973) might consider outrageous conduct ("Special Payments" have eight paragraphs out of 1,000 ).

Lonrho's criticisms, while clearly self serving, are not by any means always wide of the mark on particulars and their general complaint-that Inspectoral procedures are not well designed to secure either an unvarnished knowledge of the probable and the true or an evidently just judgement on the provably wrong-has much merit.

However, the most crucial problem lies deeper. The Investigators are working within a legal framework which makes them bound to investigate criticisms and claims, evidence and imputations suggesting actions damaging to shareholders and creditors or in violation of company law (largely directed to protecting the same groups, but having a bureaucratic and regulatory life of its own). It is open to question whether this is a suitable framework for examining a transnational group whose impact on employees and economies, heads of state and political processes, international trade and territorial development is in aggregate much more critical than its conformity to City codes, promotion of institutional and individual shareholder interests and ability to pay creditors.

Even in the given frame a territorial problem arises-are the Inspectors' concerns to be limited to the United Kingdom, its subjects and companies quoted in London? Apparently not-the treatment of minority shareholdings in some South African companies was included-but somewhat selectively so; criticisms of certain West and East African transactions were made in 1971-73 but the report steadfastly sticks to London, Rhodesia and South Africa.

As to the state of Lonrho, the Report tells us little beyond the key facts that it is and has been for 15 years the extended shadow of one manR. W. (Tiny) Rowland-that this man is not very tolerant of dissent, caution, retreat or orderly procedure so that information to the Board and shareholders (or to anyone else) is rarely either copious or unedited; that Tiny is adept at building power (political) coalitions to make deals and win struggles whether for Lonrho or for control over Lonrho, and that the concept of being seen to be free of conflicts of interest and self-dealing is one as foreign to his nature as the constraints of a normal business bureaucracy.

Cronje, Cronje and Ling in some ways paint a fuller picture, although the nature of Tiny Rowland comes through less clearly and (oddly) the narrative seems more dated. Lonrho's overall 
activities by territory and sector are covered as are some major successes (Ashanti Goldfields, Holt, Swaziland Sugar) and failures (the attempt to set up an oil consultancy to the OAU, the collapse of the Tanzanian 'province' through nationalisation) which appear fleetingly or not at all in the Inspectors' Report. However, the financial and economic analysis is scarcely more comprehensive or coherent, and in even less depth, than the Inspectors.

For the record, pre-Rowland Lonrho had a profit before tax of $£ 113,000$ in 1960 . By 1965 it was $£ 1,820,000$ and by $1975 £ 63,310,000$. (Ironically, the leader of the ousted directors, Sir Basil Smallpeice, had viewed Rowland's boast that he could achieve a $£ 50-100$ million profit as a "flight of fancy".) To that extent Tiny, the men who picked him for Lonrho (especially Messrs. Drayton, Ball, Ogilvy) and the shareholders who have backed him are right-his style does produce results. However, it is equally clear that Lonrho has a succession problem looming larger as Rowland passes each birthday and a constant danger of crisis if his judgements go sour, come in too quick succession (the real cause of the liquidity crisis), or run into obstacles beyond his control (e.g. the South African prosecution, the initially tiny band who broke the OAU arrangements, the price of copper or platinum, the pace of emission control laws, the future of Zimbabwe).

For an evaluation of what Lonrho means to its hosts' societies, one must start on one's own. The Report neither seeks to conduct such an exercise nor provides a framework for one; Cronje, Cronje and Ling's framework is rather intuitive and their presentation too episodic and impressionistic.

What then of the "unacceptable face of capitalism"? One problem here is that one group exemplified by $\mathrm{Mr}$ Heath (like Adam Smith before him) worries about businessmen's standards of morality, social concern and responsibility to those they affect beyond shareholders and creditors, and seeks to establish a professional code in this area. Another (presumably including the present Government which helped finance Lonrho's rescue of Brentford Nylons) puts its faith in outside control over businessmen and implicitly doubts the possibility of internal selfdiscipline or the "acceptable face of capitalism" (for Mr. Heath the North Sea oil exploration, where funds and careers were risked and real flows of new goods created). A third, more radical, would query the possibility of any 'acceptable' capitalism, regulated or free, bucaneering or citified, private or state.

On information, accountability and openness at Lonrho one need only quote Rowland himself :
Lonrho is in my view nothing else but Alan [Ball], yourself [Angus Ogilvy] and myself ...

Report: 441

and

the people used to troop into his various investments, 17 or 18 companies and Harley [Drayton] would say "Well we are going to sell this, we are going to buy this, and incidently he has got this, and I hope have done that", and this was the pattern and the right sort of behaviour, and the rest was sort of Christmas tree decorations. ...

Report: 451

Tiny does believe this, and his actions are consistent with the belief. Whether it works for the shareholders (who, probably rightly, feel that it is the challengers and critics rather than Rowland who have hurt them) is one thing-whether it is an acceptable way to run an institution affecting the lives of millions in tens of countries is another.

On "Special Payments" perhaps one can best quote Angus Ogilvy:

I was not against the principle or would not be against the principle of bribery because I think it has got to be done in certain countries; it is part of doing business like paying a merchant bank an underwriting fee.

Report: 638

The Inspectors ruled out study of entertainment, gifts in kind and commissions and on other payments and only concerned themselves with whether the payments were made in connection with the development of the group's business outside the UK". (Here Lonrho says "the vast majority of which were contributions to political parties in Africa, in the same way as other companies make political contributions in this country" (Statement: 7). One may wonder whether they - like the Director whom they criticise for itwere not among those who "preferred not to know the details of the payments". The US Securities and Exchange Commission (rather whimsically as a shareholder protection device!) and the Church Committee of the Senate have taken a rather tougher (or less 'realistic'?) line. On Rhodesian sanctions the case is both crystal clear and muddy. As Lonrho's solicitors warned, Lonrho's data :

discloses on its face evidence which would support a charge against company officers and personnel in London ... Counsel expressed the view, which we endorse, that there could be no defence to such a charge.

Report : 147 
Ex-Director Gerald Percy was cynically and brutally realistic in his assessment that Lonrho violated sanctions legislation and that the whole Board knew it but that so did every other UK company with major subsidiaries in Rhodesia. Mr. Rowland--fairly frequently and not only in the Statement and Memorandum-has pointed to the key role of UK based banks and of British Petroleum inter alia in sanctions busting. As a defence this may be weak, as a criticism it is cogent. Lonrho has not been charged with sanction offences. The UK rejects the operative sections of the World Court Judgement on Southwest Africa (Namibia) because to do so would make it a receiver (or a party to a conspiracy to steal) in respect of the contracts for purchase of Rossing Uranium.

Rowland has criticised Smith, has provided legal advice to Nkomo, has built up Lonrho and personal assets in Rhodesia, has at the least channelled the benefits of actions helping sustain UDI to Lonrho and to himself. There is in this no inconsistency for him-as Cronje, Cronje and Ling show on a wider canvas, his goal is to make money with whatever partners and in whatever political setting is conducive to that end.

A final key issue remains obscure-how does Lonrho make money? It is not an asset stripper : if anything it tends to squirrel away ill-assorted and none too promising companies like nuts. Nor is it a technology and management powerhousethe quality of acquisition performance seems quite unaltered by Lonrho's takeover. Nor does Lonrho seem to produce much that was not fairly sure to be produced anyway.

Lonrho seems to be a conglomerate based on the timely acquisition of companies whose profits were about to rise anyhow, projects needing finance for a 'ripe' scheme and sound companies for some reason on the bargain counter. Rowland is an entrepreneur of financial opportunities, not of knowledge or production or management. This has paid his shareholders and not injured his creditors. It probably does not harm group employees. But what of customers, host states, exowners? Is the feeling that there is a real difference between he who makes more or better and he who juggles sums (even if within the law) totally wrong? In terms of UK company law it probably is. Equally, is the image that Hedsor Wharf, the Mystère jet, the overseas payments (to politicians or to tax-avoiding employees), the carefully structured band of Board brothers (Rowland-Ball-Ogilvy via Yeoman), really acceptable if due disclosure is made to Board and shareholders?

\section{Books received}

Juan Martinez-Alier, Haciendas, Plantations and Collective Farms Frank Cass, London 1977. $£ 8.50$

H. Joshi, H. Lutell, J. Monly, Abidjan. Urban development and employment in the Ivory Coast International Labour Office, Geneva 1976. 30sw. frs.

Khodadad Farmanfarmaian (Ed.), The Social Sciences and Problems of Development Princeton University Program in Near Eastern Studies, Princeton, NJ USA 1976

Stephen H. Hellinger and Douglas A. Hellinger, Unemployment and the Multinationals Kennikat Press Corp. Port Washington, NY 1976. $\$ 12.50$

Olle Nordberg, Peter Phillips and Göran Sterky (Eds.), Action for Children. Towards an Optimum Child Care Package in Africa The Dag Hammarskjold Foundation, Uppsala, Sweden 1975. Skr 30

Jack Parsons, Population Fallacies E'ek/Pemberton Publishing Co. Ltd, London 1977. $£ 4.00$

Brian Wren, Education for Justice SCM Press Ltd, London 1977. $£ 2.50$

Lord Walston, Dealing with Hunger The Bodley Head, London 1976

Gerald Leach, Energy and Food Prodaction IPC Science and Technology Press Ltd, Guildford 1976. $£ 5.50$

Fritz Machlup (Ed.), Essays on Hayek New York University Press, NY 1976

P. F. Dale, Cadastral Surveys within the Commonwealth HMSO Books, London 1977. £4.35

Philip G. Allbach and Sheila McVey (Eds.), Perspectives on Publishing Lexington Books, Massachusetts, USA 1976. $£ 21.00$ 